\title{
Dosimetry of ${ }^{131}$ I for Occupational Radiation Workers by Whole Body Counting System
}

\author{
M. S. Rahman ${ }^{1, \star}$, M. A. Haydar ${ }^{1}$, M. K. A. Patwary ${ }^{2}$, S. M. Shome ${ }^{1}$, S. Paul ${ }^{1}$, \\ D. Paul ${ }^{1}$, A. K. M. M. H. Meaze ${ }^{3}$ \\ ${ }^{1}$ Secondary Standard Dosimetry Laboratory, Health Physics and Radioactive Waste Management Unit \\ Bangladesh Atomic Energy Commission, Savar, Dhaka 1000, Bangladesh \\ ${ }^{2}$ Department of Natural Science, Port City International University, \\ Chittagong 4225, Bangladesh \\ ${ }^{3}$ Department of Physics, University of Chittagong, Chittagong 4331, Bangladesh \\ *E-mail address: shakilurssdl@yahoo.com
}

\begin{abstract}
Internal radiation dosimetry of occupational radiation workers due to inhalation of ${ }^{131} \mathrm{I}$ during maintenance at iodine ${ }^{131} \mathrm{I}$ hot cell of Radioisotope Production Division (RIPD) of Bangladesh Atomic Energy Commission have been performed with Whole Body Counter (WBC) containing two large size $\mathrm{NaI}$ detector. The contaminated radioactivity of the radiation workers by ${ }^{131} \mathrm{I}$ was immediately conducted using a WBC (CANBERRA, FASTSCAN model 2250) and counting was repeated again a few days later. The performance of whole body counter was checked by CANBERRA transfer phantom (model 2257$)$ with a mixed source $(20 \mathrm{ml}$ vial). The intake was calculated by Apex-Invivo counting software and then corresponding dose in thyroid were estimated by using Integrated Modules for Bioassay Analysis (IMBA) Professional Plus code modules. The body activity due to intake of ${ }^{131} \mathrm{I}$ and the total effective and equivalent dose in thyroid were also estimated and discussed.
\end{abstract}

Keywords: Internal Dosimetry; Whole Body Counter; IMBA; ${ }^{131} \mathrm{I}$

\section{INTRODUCTION}

Occupational radiation workers are exposed to natural and man-made sources by external exposure and/or internal contamination. Internal exposure arises when radiation is emitted from radioactive materials present within the body [1]. The internal dose is directly related to the intake of radioactive materials, which are introduced into the body by inhalation, ingestion or through the skin (absorption, injection, etc.) [2]. Internal contamination continues until the radioactive material is cleared from the body by natural processes or is removed by medical countermeasures. All forms of radiation can cause internal radiation exposures. According to the technical guidance from the International Commission on Radiological protection (ICRP) and technical reports or papers, the iodine is classified as a radionuclide which is difficult to measure and to estimate internal exposure [3]. Occupational exposure to ${ }^{131} \mathrm{I}$ occurs in the nuclear industry, in research and in nuclear medicine, in both diagnostic and therapeutic settings [4,5]. Generally, with ${ }^{131} \mathrm{I}$, an individual is exposed to beta particles (average energy for main emission is $0.19 \mathrm{MeV}$ ) and gamma rays 
(main emission $0.36 \mathrm{MeV}$ ) [6]. In particular, iodine inside the body is fast to be absorbed into organs and to excrete from organs. Some are concentrated at thyroid and then removed because of its high volatility and chemical characteristics $[3,7,8]$.

${ }^{131}$ I is produced by the irradiation of ${ }^{130 \mathrm{~m}} \mathrm{Te}[(\mathrm{n}, \gamma)$ reaction $\left.)\right]$ has a half-life of 8.04 days, but its effective half life in the body is reduced to 7.3 days because of some physiological processes. Iodine is rapidly absorbed in the blood following intake, whereas about $70 \%$ is excreted in the urine and about $30 \%$ concentrates in the thyroid $[9,10]$. The biological half life of iodine in the blood is quite short, about 6 hours, because of these two mechanisms; the much longer 80 day biological half life in the thyroid, where it is incorporated into thyroid hormones that subsequently enter other tissues [11], accounts for the overall effective half life in the body of 7.3 days. ${ }^{131} \mathrm{I}$ may be detected directly in the thyroid or indirectly in urine samples. According to ICRP publications 54 and 78 for guidance of internal dosimetry, the activity of ${ }^{131} \mathrm{I}$ after inhalation increases rapidly until 1 or 2 days after inhalation, and then its activity decreases gradually $[3,8]$. Thus, it was concluded that after 1 or 2 days of inhalation the activity of ${ }^{131}$ I inside the body reaches equilibrium and it becomes possible to do a steady whole body counting.

In the present study, during the maintenance work of ${ }^{131} \mathrm{I}$ hot cell at Radioisotope Production Division (RIPD) of Institute of Nuclear Science \& Technology (INST), Atomic Energy Research Establishment (AERE), Savar, Dhaka, the occupational radiation workers were exposed internally due to the release of ${ }^{131} \mathrm{I}$ inside the facility. The internal contamination of the 8 (eight) radiation workers contaminated by ${ }^{131} \mathrm{I}$ was conducted immediately using CANBERRA FASTSCAN whole body counting system. In the present study the distributions of iodine concentration within different organs especially in thyroid were estimated by IMBA professional plus software [12].

\section{METHODS AND MATERIALS}

\section{1. Whole Body Counter}

The CANBERRA FASTSCAN Whole Body Counter consists of two large NaI (Tl) detectors, arranged in a linear array on a common vertical axis. The sizes of the detectors are each of $7.6 \mathrm{~cm} \times 12.7 \mathrm{~cm} \times 40.6 \mathrm{~cm}$ with Apex-Invivo (SU-734-4) software to achieves low minimum detectable activities (MDA) with count time as fast as one minute [13]. The detectors are shielded in all straight line directions by $10 \mathrm{~cm}$ of especially low background steel to minimize spectral background interference. Each test subject enters the counting shield and leans against the back wall. There are molded positioning devices on the back wall that make it natural for the individual to stand in the correct location. The operator starts the count using the Apex-Invivo counting software included with the system. The software starts the data collection and brings up a subject demographics screen, as shown in Fig. 1.

\section{2. Efficiency Calibration}

Efficiency calibrations are performed by using the RMC-II transfer phantom. This phantom is designed to be an inexpensive, easy to use analog of the Humanoid Systems Livermore realistic torso Lung Phantom, the BOMAB Uniform Concentration Total Body and GI phantom, and the ANSI 44.3 Thyroid Phantom [13], which is shown in Fig. 2.

Efficiency calibrations of the detectors of the counting system were done for thyroid, lung, whole body, gastrointestinal tract (Lower torso geometries) and rear wall (Empty shield measurement) with a solid source matrix in a $20 \mathrm{ml}$ liquid scintillation vial placing at the 
different position in the phantom. Calibration result for thyroid and whole body position is given in Fig. 2.

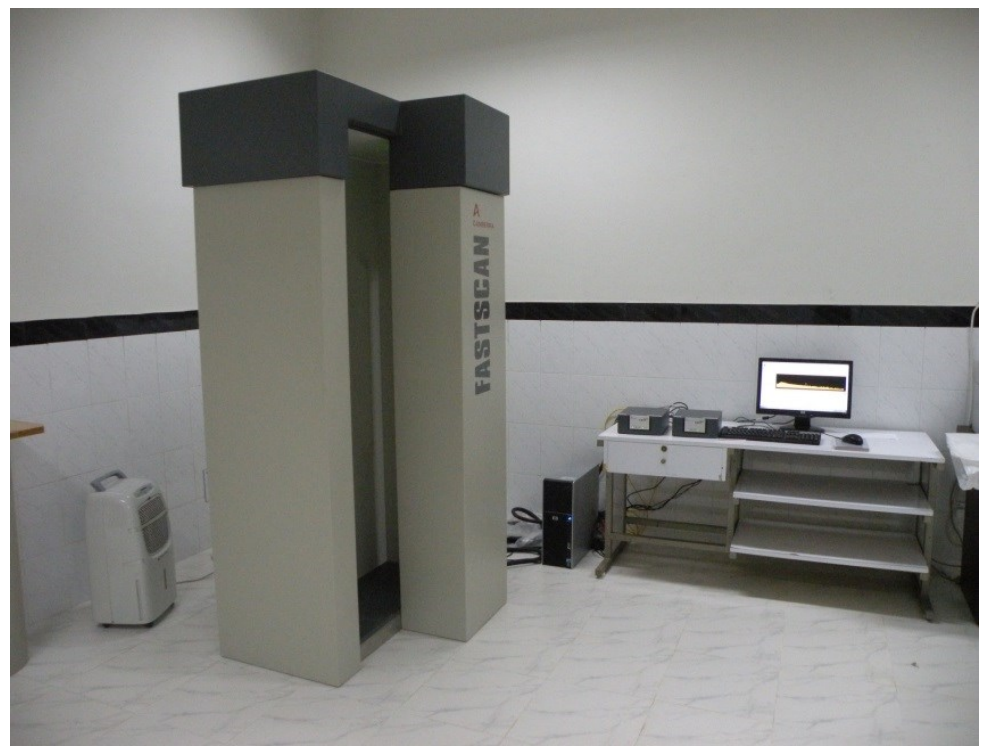

Figure 1. CANBERRA FASTSCAN Whole Body counting arrangement (model 2250).

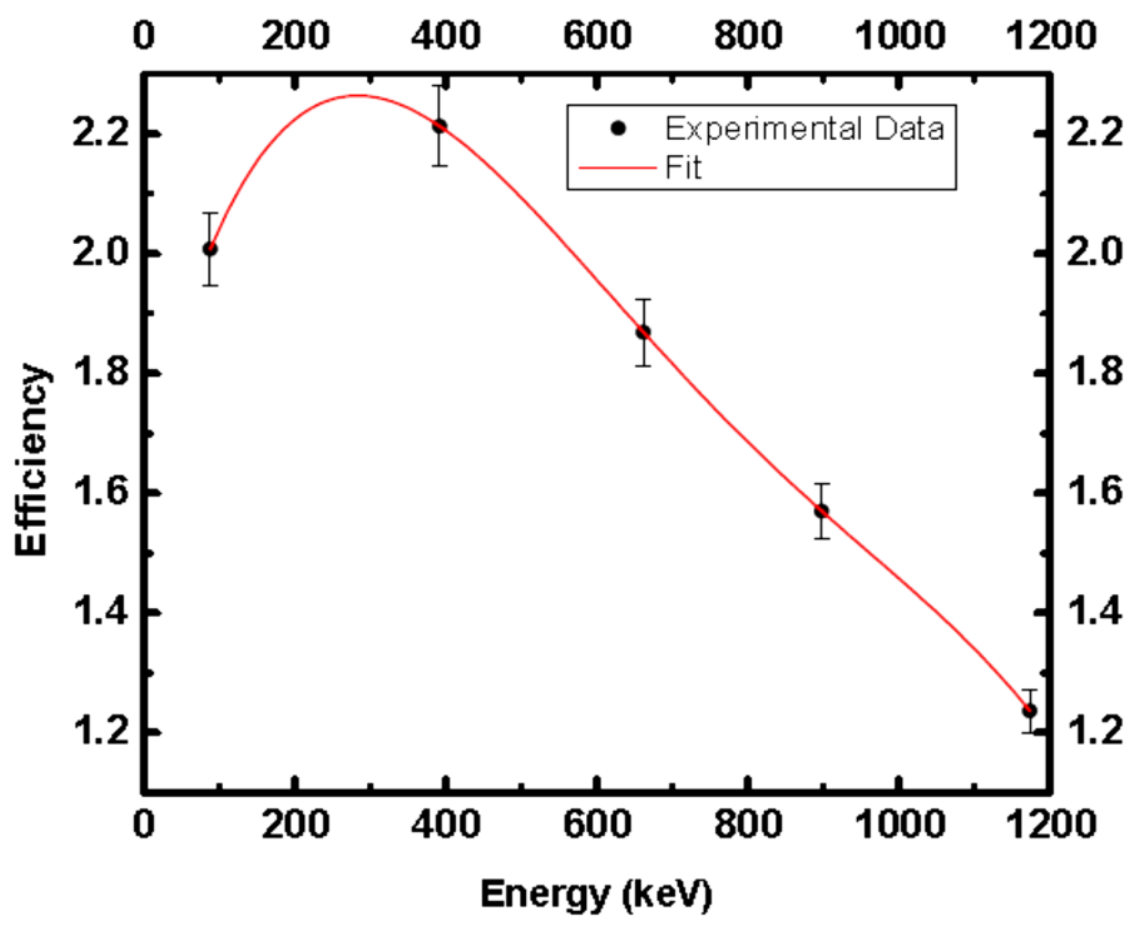

Figure 2. Efficiency calibration curve in thyroid in the CANBERRA transfer phantom with $20 \mathrm{ml}$ liquid scintillation vial.

\section{3. Integrated Modules for Bioassay Analysis (IMBA) Professional Plus}

IMBA professional plus (version 4.1.13) code modules were used to estimate single or multiple intakes of various radionuclides, and to calculate the resulting doses from measurements of activity in the body and/or excreta. The IMBA code modules implement all of the International Commission on Radiological Protection's (ICRP's) currently 
recommended respiratory tract, GI-tract, tissue dosimetry, biokinetic and bioassay models for the selected radionuclide's, for the ICRP 68 Reference Worker [12]. Since all the workers in the present study are perfect adult and they are working continuously in the same environment thus considering all these items and for ${ }^{131}$ I total effective dose and total equivalent dose have been found using IBMA. Using this software total effective dose and total equivalent dose were calculated in 37 different organs inside the workers but concentration of ${ }^{131} \mathrm{I}$ in the thyroid was main focus.

\section{RESULT AND DISCUSSION}

In the present study 33 occupational radiation workers were scanned by Whole Body Counter to observe whether they contaminated internally or not and hereby only 08 workers were found positive for ${ }^{131} \mathrm{I}$. In this case, both the thyroid and whole body geometries were used for whole body counting, but for intake estimation, the detected internal activity from the whole body geometry was used, which provided more conservative results. The body activity of ${ }^{131} \mathrm{I}$ from whole body counter together with the value of total effective dose \& total equivalent dose from IMBA Professional Plus enlisted in Table 1.

Since it was concluded that after 1 to 2 days of inhalation the activity of ${ }^{131} \mathrm{I}$ inside the body reaches equilibrium and it becomes possible to do a steady whole body counting. Therefore, the body activity for different workers was recorded after 1 to 2 day of inhalation and count was repeated for several times depending on the activity.

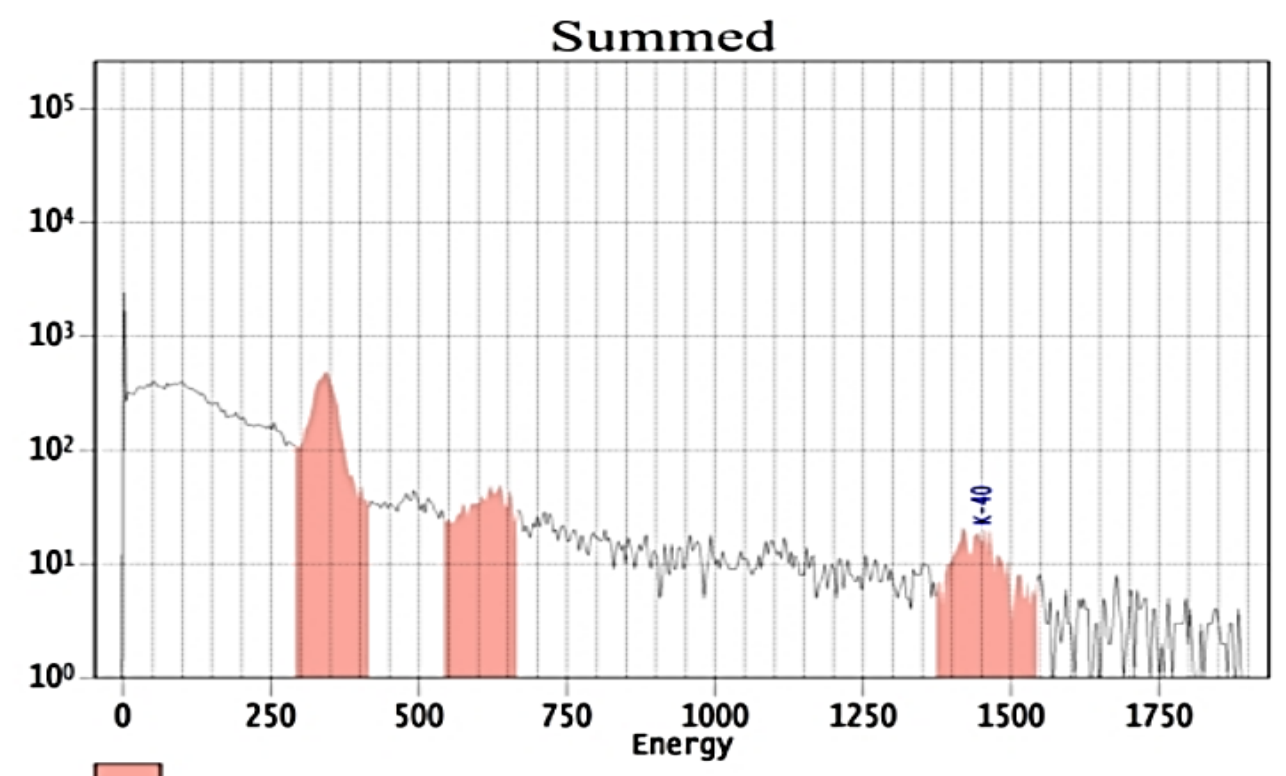

ROI Type: 1

Figure 3. A typical gamma ray energy spectrum obtained from CANBERRA FASTSCAN Whole Body Counting system. 


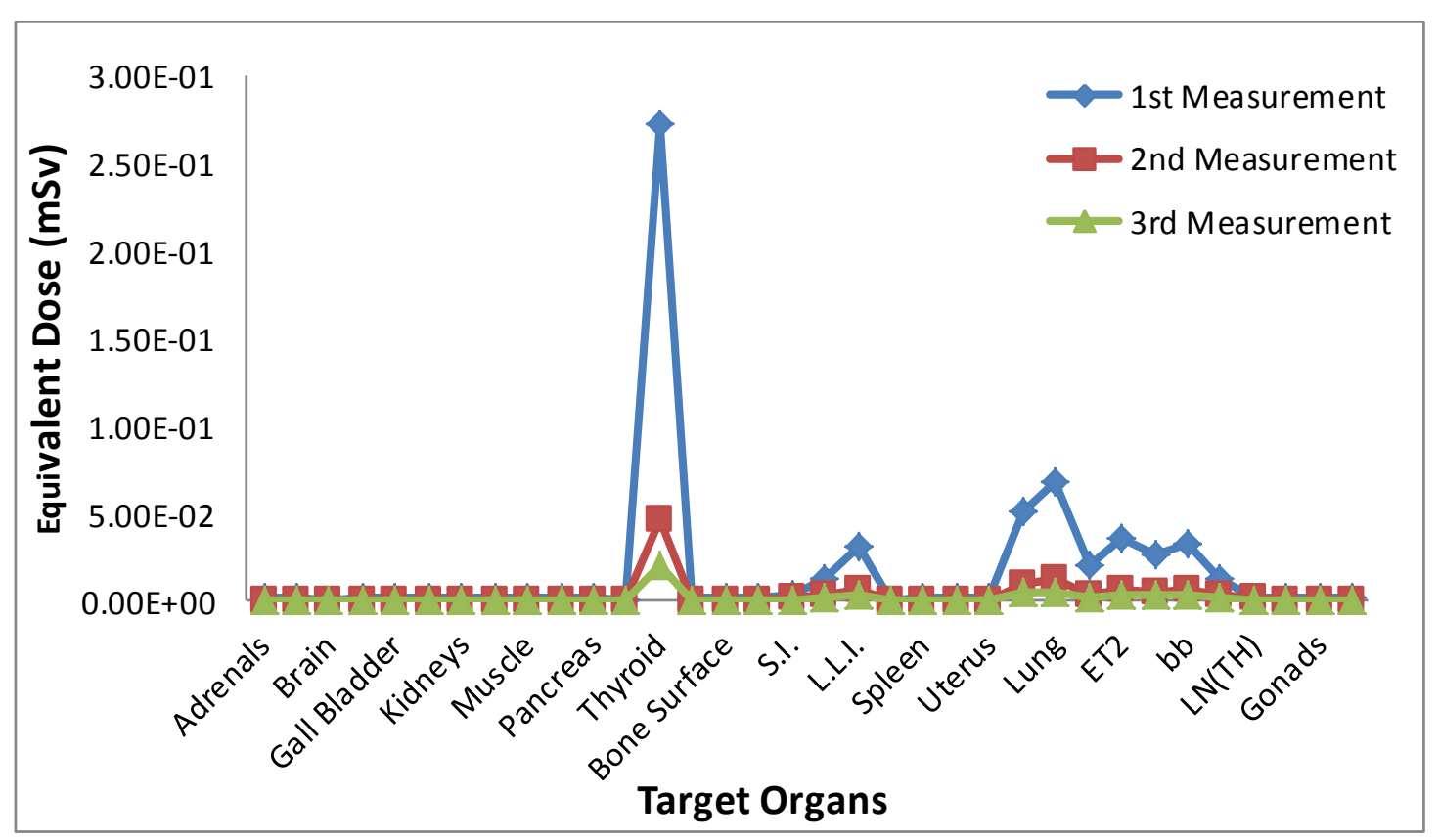

Figure 4. A typical decay pattern of organs doses obtained from IMBA Professional Plus software.

From Table 1 it was observed that 1 day after the body activity of different radiation workers was varied from $368.56 \mathrm{~Bq}$ to $8859.2 \mathrm{~Bq}$. It was also seen that the maximum total effective dose and equivalent dose in $\mathrm{mSv}$ after 1 to 2 day of exposure were $0.025 \mathrm{mSv}$ and $0.273 \mathrm{mSv}$, and decayed to $0.004 \mathrm{mSv}$ and $0.020 \mathrm{mSv}$, respectively after 5 to 7 days. Moreover, from the repeated measurement it was observed that the body activity, total effective dose, and total equivalent dose were decreases gradually for almost all the radiation workers.

Occupational limits for radionuclide exposure address ingestion, inhalation, and external exposure are set by the Nuclear Regulatory Commission (NRC) for NRC licensees and by the Department of Energy for DOE facilities. The NRC limits are intended to ensure that no worker exceeds $50 \mathrm{mSv}$ ( $5 \mathrm{rem}$ ) of ${ }^{131}$ I to the whole body or $500 \mathrm{mSv}$ (50 rem) to the thyroid, and that no member of the public exceeds $1 \mathrm{mSv}(0.1 \mathrm{rem})$ to the whole body [14]. Hence contaminated individuals were exposed internally to less than the average annual dose limit for workers [15]. A typical gamma-ray energy spectrum for a radiation worker is shown in Fig.3. The prominent photo-peak that can be observed from the spectrum is due to the photo-peak of ${ }^{131} \mathrm{I}$ at $364.48 \mathrm{keV}$ and $636.98 \mathrm{keV}$. As mentioned above the IMBA Professional Plus software was used for the estimation of total effective dose and equivalent dose for different organs inside the workers. Since the maximum body activity of $8859.20 \mathrm{~Bq}$ was observed (Table 1) for radiation worker with ID RW4010.

Therefore, the distribution of the estimated organs doses for that worker has been graphically presented in Fig.4.The calculations were performed considering that the inhaled activity with normal rate of retention and the radioactive isotope uptake would be at the thyroid gland. The graph depicts that the worker received the maximum organ dose of 2.73E$01 \mathrm{mSv}$ to thyroid after 1 day of exposure and decayed to $1.98 \mathrm{E}-02 \mathrm{mSv}$ after $3^{\text {rd }}$ measurement. 
Table 1. Total Effective \& Equivalent Dose due to ${ }^{131}$ I Distributed in Thyroid.

\begin{tabular}{|c|c|c|c|c|c|c|c|c|c|}
\hline \multirow{2}{*}{$\begin{array}{c}\text { Personnel } \\
\text { ID }\end{array}$} & \multicolumn{2}{|c|}{$\begin{array}{c}\text { 1st Measurement } \\
\text { (after 1 to 2 day) }\end{array}$} & \multicolumn{2}{c|}{$\begin{array}{c}\text { 2nd Measurement } \\
\text { (after 3 to 4 days) }\end{array}$} & \multicolumn{3}{|c|}{$\begin{array}{c}\text { 3rd Measurement } \\
\text { (after 5 to 7 days) }\end{array}$} \\
\cline { 2 - 10 } & $\begin{array}{c}\text { Activity of } \\
\text { Intake } \\
\text { (Bq) }\end{array}$ & $\begin{array}{c}\text { Total } \\
\text { Effective } \\
\text { Dose } \\
\text { (mSv) }\end{array}$ & $\begin{array}{c}\text { Equivalent } \\
\text { Dose for } \\
\text { Thyroid } \\
\text { (mSv) }\end{array}$ & $\begin{array}{c}\text { Activity of } \\
\text { Intake } \\
\text { (Bq) }\end{array}$ & $\begin{array}{c}\text { Total } \\
\text { Effective } \\
\text { Dose } \\
\text { (mSv) }\end{array}$ & $\begin{array}{c}\text { Equivalent } \\
\text { Dose for } \\
\text { Thyroid } \\
\text { (mSv) }\end{array}$ & $\begin{array}{c}\text { Activity of } \\
\text { Intake } \\
\text { (Bq) }\end{array}$ & $\begin{array}{c}\text { Total } \\
\text { Effective } \\
\text { Dose } \\
\text { (mSv) }\end{array}$ & $\begin{array}{c}\text { Equivalent } \\
\text { Dose for } \\
\text { Thyroid } \\
\text { (mSv) }\end{array}$ \\
\hline RW2002 & 1202.97 & 0.003 & 0.037 & 816.98 & 0.003 & 0.028 & 761.89 & 0.002 & 0.024 \\
\hline RW2003 & 547.59 & 0.002 & 0.017 & 326.52 & 0.001 & 0.009 & 204.94 & 0.001 & 0.007 \\
\hline RW2010 & 368.56 & 0.001 & 0.011 & 262.52 & 0.001 & 0.008 & & & \\
\hline RW2012 & 4869.84 & 0.014 & 0.150 & N/A* & & & N/A & & 0.01 \\
\hline RW2016 & 1053.00 & 0.003 & 0.032 & 919.99 & 0.002 & 0.017 & 238.53 & 0.001 & 0.014 \\
\hline RW4005 & 4400.00 & 0.012 & 0.135 & 4249.54 & 0.012 & 0.131 & & & 0.004 \\
\hline RW4007 & 1790.74 & 0.005 & 0.055 & $<$ MDA** & & & $<$ MDA & \\
\hline RW4010 & 8859.20 & 0.025 & 0.273 & 1463.82 & 0.002 & 0.045 & 642.87 & 0.004 \\
\hline
\end{tabular}

N/A* $=$ Not available for recount

$\mathrm{MDA}^{* *}=$ Minimum Detectable Activity

\section{CONCLUSION}

Since ${ }^{131}$ I enter into the human body mostly in the process of inhalation because of its vapor state so radiation workers mentioned in the present study are contaminated by ${ }^{131} \mathrm{I}$ during maintenance period. However, 08 occupational radiation workers were found as ${ }^{131} \mathrm{I}$ contaminated but their body activity and then total effective dose, total equivalent dose from IMBA analysis were not effective for making any harmful condition in the body circulation. From the present study, it could be recommended that although radiation doses received by the critical organs like thyroid are small, precaution must be taken to minimize unnecessary doses. Present study describes only a case further study is required.

\section{Acknowledgement}

The authors would like to express their sincere thanks to the Director, Institute of Nuclear Science \& Technology (INST), and Head, Health Physics and Radioactive Waste Management Unit (HPRWMU), INST of Bangladesh Commission for their administrative and logistic support. This research work was a part of Master of Science thesis work of the 1st author. The whole research work was performed at the Secondary Standard Dosimetry Laboratory, AERE, Savar, Dhaka under the institutional activity program of Bangladesh Atomic Energy Commission. The instrumental support that was given for this research work was established under Annual Development Project (ADP) "Strengthening of Secondary Standard Dosimetry Laboratory (SSDL) Facilities" of Ministry of Science and Technology, Government of Peoples Republic of Bangladesh. 


\section{References}

[1] M.I. Gohary, M.A. Gomaa, Samia M. Rashad, Eid M.A., T.M. Morsi, Internal Dosimetry of ${ }^{40} \mathrm{~K}$ and ${ }^{131} \mathrm{I}$ in Egyptian Radiation Workers 24(3) (2010).

[2] International Atomic Energy Agency, Occupational Radiation Exposure, Safety Standard Series, 1999.

[3] International Commission on Radiological Protection, Individual Monitoring for Internal Exposure of Workers Replacement of ICRP Publication 54, ICRP Publication 78. (1997).

[4] Kocher David C., Radioactive decay data tables, 1981, p. 131.

[5] MDS Nordion division. Nordion is a trademark of MDS (Canada) June 2008. www.mds.nordion.com/documents/products/131I-Solu_Can.pdf

[6] International Commission on Radiological Protection, Radionuclides Transformations: Energy and Intensity of Emissions, Publication-38, 1983.

[7] United State Nuclear Regulatory Commission, Regulatory Guide 8.20: Application of Bioassay for I-125 and I-131, USNRC, (1979).

[8] International Commission on Radiological Protection, Individual Monitoring for Intakes of Radionuclides by Workers: Design and Interpretation, ICRP Publication 54. (1987).

[9] International Commission on Radiological Protection, Age Dependent Doses to Members of the Public from Intake of Radionuclides, part 1, publication 56, 1989.

[10] International Commission on Radiological Protection, Dose Coefficients for Intakes of Radionuclides by Workers, publication 68, 1994.

[11] International Commission on Radiological Protection, "Limits for Intakes of Radionuclides by Workers" Publication 30, part 1, 1979.

[12] http://www.imbaexpert.com.

[13] Factory Efficiency Calibration of the Canberra Apex-Invivo Lynx FASTSCAN whole body counter for Bangladesh Atomic Energy Commission (Canberra, USA) (2011).

[14] "Radiation Exposure from I-131", Course: SS3117, Agency for Toxic Substances and Disease Registry Division of Toxicology and Environmental Medicine, U.S.

Department of Health and Human Services, Nov. 2002, 31.

[15] 2007 ICRP Recommendations, Publication 103, (2007). 